\title{
Pendampingan dalam Mehamami Indeks Kebahagiaan Guru di Madrasah Aliyah Negeri (MAN) di Tangerang Selatan
}

\author{
Nurochim \\ Program Studi Manajemen Pendidikan, Fakultas Ilmu Tarbiyah dan Keguruan, UIN Syarif \\ Hidayatullah Jakarta, Indonesia \\ nurochim@uinjkt.ac.id \\ Siti Ngaisah \\ Departement Penelitian Dan Pengabdian Masyarakat, CIC Lembaga Riset dan Konsultan Sosial, \\ Depok, Indonesia \\ sitingaisahcic@gmail.com
}

Naskah diterima: 8 Desember 2019| Naskah disetujui: 30 Januari 2020

\begin{abstract}
The educational environment is a place where a group of people gather for a long time. In addition, the school is an educational institution that aims to achieve the vision and mission of education. Principals and teachers are human resources, as the driving force for achieving educational goals. Therefore these human resources must be managed properly. Good management starts with understanding the individual, that is feeling happy. Feelings of happiness will make the education human resources can carry out their duties properly. Therefore, community empowerment is important to be implemented to understand the meaning of happiness. The result of this empowerment is that the teacher's happy feelings are quite high. This is seen from the understanding of each dimension namely life satisfaction, feelings, and the meaning of life. However, there are sub-dimensions that are still low, such as conditions for career advancement and teacher competence, and the lack of teacher opportunities to improve academic quality. It is therefore important for policy makers to carry out further studies and empowerment based on teachers. So the teacher can carry out the task well.

Keyword: teacher, happiness, life satiscaftion, affect, meaning of life
\end{abstract}

\begin{abstract}
Abstrak
Lingkungan pendidikan merupakan tempat sekelompok orang berkumpul dalam waktu yang lama. Selain itu sekolah merupakan salah satu lembaga pendidikan yang bertujuan untuk mencapai visi dan misi pendidikan. Kepala sekolah dan guru merupakan sumber daya manusia, sebagai penggerak tercapainya tujuan pendidikan. Oleh karena itu sumber daya manusia tersebut harus dikelola dengan baik. Pengelolaan yang baik dimulai dengan memahami individu, yakni perasaan bahagia. Perasaan bahagia akan membuat sumber daya manusia pendidikan dapat melaksanakan tugasnya dengan baik. Oleh kerena itu pemberdayaan masyarakat penting dilaksanakan untuk memahami makna kebahagiaan tersebut. Hasil pemberdayaan ini adalah menunjukkan perasaan bahagia guru cukup tinggi. Hal tersebut dilihat dari pemahaman masing-masing dimensi yakni kepuasan hidup, perasaan, dan makna hidup. Namun demikian, ada sub dimensi yang masih rendah, seperti kondisi
\end{abstract}


peningkatan karir dan kompetensi guru, dan kurangnya kesempatan guru untuk meningkatkan kualitas akademik. Oleh karena itu penting bagi para pemangku kebijakan untuk melaksanakan kajian dan pemberdayaan lebih lanjut yang berbasis pada guru. Sehingga guru dapat melaksanakan tugas dengan baik.

Kata Kunci: guru; kebahagiaan; kepuasan hidup; perasaan; makna hidup

\section{Pendahuluan}

Manusia membutuhkan kebahagiaan dalam menjalani kehidupan, oleh karena itu kebahagiaan merupakan salah satu hal kebutuhan penting. Kebahagiaan merupakan masalah yang kompleks, yakni kebahagiaan secara menyeluruh, termasuk perasaan dalam kehidupan keseharian dan kepuasan terhadap kehidupan tersebut. Faktor yang mempengaruhi kebahagiaan ada beberapa, seperti keturunan, pendidikan, kesehatan, pekerjaan dan kondisi keuangan. Namun demikian sikap batin manusia dalam menemukan nilai-nilai dan tujuan hidup juga mempengaruhi kebahagiaan (Ica Haiti, 2018).

Survey mengenai kebahagiaan sudah dilaksanakan oleh Biro Pusat Statistik pada tahun 2014. Pada tahun 2017 diumumkan bahwa pertumbuhan ekonomi mencapai angka $5 \%$ hal ini termasuk tinggi untuk ukuran Asia Pasifik. Namun jika dilihat dari aspek ekonomi indeks Gini berkisar pada angka 0.40, hal ini menunjukkan bahwa terdapat kesenjangan ekonomi yang serius. Selain itu adanya tindak kriminalitas yang tinggi juga menunjukkan bahwa kesejahteraan sosial di Indonesia juga masih kurang. Banyaknya perkelahian antar pelajar di sekitar Ibu kota (Haryudi, 2018), juga menjadi salah satu indikator mengenai masih rendahnya kesejahteraan sosial pada lingkungan pendidikan. Setidaknya pada tahun 2016 ada 10 tawuran antara pelajar yang mengakibatkan kematian dan korban luka (10 Tawuran Pelajar Yang Merenggut Jiwa di Tahun 2016 - Serba Top 10, 2016).

Konsep memajukan kesejahteraan umum, menurut konstitusi Indonesia, merupakan konsep yang menggambarkan sebuah proses pencapaian tingkat kesejahteraan masyarakat yang sekaligus menggambarkan perkembangan sosial masyarakat (progress of society). Konsep kesejahteraan, sebagaimana dinyatakan oleh para pendiri Negara Kesatuan Republik Indonesia, tampaknya tidak hanya untuk menggambarkan kondisi kemakmuran material (welfare, being-well atau prosperity), tetapi juga mengarah kepada konsep kebahagiaan (happiness). Kebahagiaan memiliki makna dan cakupan yang tidak hanya terbatas pada kondisi kehidupan yang menyenangkan (pleasant life) dan kondisi kehidupan yang baik (being-well atau good life), tetapi juga pada kondisi kehidupan yang bermakna (meaningful life). Dalam konteks ini, konsep kebahagiaan menjadi topik pembangunan nasional yang mendapat perhatian lebih besar dibandingkan dengan konsep kesejahteraan material maupun kemakmuran ekonomi (Dewasasri M. Wardani, 2016).

Survei kebahagiaan merupakan salah satu dari survei tingkat nasional pada saat ini. Survey kebahagiaan pada tingkat nasional diselenggakan oleh Biro Pusat Statistik (BPS). Survey ini berfokus pada kebahagiaan subjektiv dan objektiv individu. Pada bulan Agustus 2017, BPS merilis data indeks kebahagiaan penduduk Indonesia. Indeks kebahagiaan penduduk Indonesia pada tahun 
2017 sebesar 70,69 pada skala 0-100 (Badan Pusat Statistik, 2017). Pada tahun 2017 metode pengukuran indeks menggunakan dimensi kepuasan hidup, perasaan (affect), dan makna hidup.

Penelitian tentang kebahagiaan yang sudah dilakukan, belum dilaksanakan secara spesifik pada kelompok pendidik atau guru. Hal ini penting dilakukan sebab untuk mendukung pengembangan dan perbaikan kebijakan pengelolaan pendidik. Kebijakan pengelolaan pendidik seharusnya memperhatikan aspek sosial dan individual. Sehingga kebijakan dapat diimplementasikan dengan penuh tanggung jawab oleh seluruh komponen pendidikan termasuk guru. Dalam sistem pendidikan di Indonesia, guru merupakan pendidik profesional dengan tugas utama mendidik, mengajar, membimbing, mengarahkan, melatih, menilai, dan mengevaluasi peserta didik pada pendidikan anak usia dini jalur pendidikan formal, pendidikan dasar, dan pendidikan menengah (UU No. 14 Tahun 2005). Dapat dipahami bahwa pemahaman akan jati diri seorang guru pada setiap jenjang pendidikan menjadi kunci keberhasilan dalam mengajar.

Kebahagiaan guru adalah permasalahan atau fenomena yang kompleks. Kebahagiaan guru dengan berbagai faktor penentu. Penelitian tentang kebahagiaan guru memerlukan data yang luas dan mendalam. Dengan adanya penelitian fenomena kebahagiaan guru dengan luas dan mendalam maka dapat mendukung adanya perhatian terhadap kebahagiaan guru, sehingga guru dapat melaksanakan tugas dengan optimal. Terlebih guru di Madrasah memiliki tanggung jawab tidak hanya memberikan pemahaman keilmuan namun juga harus memberikan pembelajaran moral dan iman. Dengan tugas dan tanggung jawab tersebut maka kebahagiaan guru merupakan hal yang sangat penting, guna melaksanakan tugas dengan optimal.

Guru yang goncang atau tidak stabil emosinya, hal tersebut ditinjukkan dengan kondisi yang mudah cemas, penakut, pemarah, penyedih dan pemurung. Hal tersebut menyebabkan anak didik akan terombang-ambing dibawa oleh arus emosi guru yang goncang. Biasanya guru yang tidak stabil emosinya tersebut tidak menyenangkan bagi anak didik. Kegoncangan perasaan anak didik itu akan menyebabkan kurangnya kemampuannya untuk menerima dan memahami pelajaran, sebab konsentrasi pikirannya diganggu oleh perasaannya yang goncang karena melihat guru yang goncang.

Guru yang pemarah atau keras, akan menyebabkan anak didik takut. Ketakutan itu dapat bertumbuh atau berkembang menjadi benci. Karena takut itu menimbulkan derita atau ketegangan dalam hati siswa, maka guru tersebut akan dijauhi siswa. Akan tetapi sebagai anak didik yang harus patuh dan tunduk kepada peraturan sekolah, ia terpaksa tetap berada dalam kelas, ketika guru tersebut ada, maka lambat laun guru itu akan menjadi guru yang dibenci oleh anak didiknya. Apabila anak didik benci kepada guru, maka ia tidak akan berhasil mendapatkan bimbingan dan pendidikan dari guru tersebut.

Namun demikian Eki (2013) mengungkapkan bahwa kebahagiaan guru disebabkan karena siswa yang diajarnya menjadi orang sukses, memiliki jabatan terhormat di masyarakat, memiliki sikap sopan santun, dapat melanjutkan pendidikan ke jenjang yang lebih tinggi dan berprestasi baik akademik maupun non akademik. Hal selanjutnya menurut Eki, guru bahagia jika siswa memberikan apresiasi atau pujian tentang metode mengajar yang digunakan dapat memberikan 
pemahaman pada materi pelajaran, selain itu guru akan bahagia jika siswa memberikan pujian tentang wawasan materi pelajaran yang luas (Eki Akhwan, 2013).

Pengukuran kebahagiaan tentu saja berarti menguantifikasikan sesuatu yang kualitatif. Ini sangat berbeda dari pengukuran dalam ilmu alam yang objektif dan kuantitatif. Manusia adalah makhluk yang bukan hanya rasional tetapi juga emosional, karena itu pendapat dan persepsi manusia akan sangat dipengaruhi oleh situasi dan kondisi emosinya saat ini. Ketika seseorang senang dan berbahagia bisa jadi ia melihat hidup ini lebih indah dan karenanya cenderung memberikan penilaian yang positif. Sebaliknya, ketika sedang dalam kondisi yang kurang menyenangkan, maka ia cenderung memberikan penilaian yang negatif (Arvan Pradiansyah, 2013).

Kebahagiaan juga dipengaruhi oleh kehidupan keluarga dan sosialnya, seperti keluarga yang harmonis, hubungan dengan tetangga, sahabat, serta orang lain yang terjalin dengan baik, tidak memiliki musuh, serta selalu menghargai orang lain. Termasuk lingkungan yang aman dan nyaman juga mempunyai andil dalam membuat meningkatnya kepuasan hidup. Rasa aman dari tindak kejahatan, perilaku sosial yang buruk, seperti terjadinya aksi kriminalitas, perkelahian massal, dan sejenisnya, serta dampak dari polusi dan bencana alam juga menjadi faktor penentu kepuasan hidup. Perasaan dan maka hidup merupakan bagaimana individu merasakan kehidupan mereka, merasakan orang-orang di sekeliling, dan merasayakan masyarakat tempat individu tersebut hidup (Koo et al., 2016).

BPS membuat perbandingan indeks kebahagiaan berdasarkan klasifikasi wilayah, jenis kelamin, status perkawinan dan kelompok umur. Namun BPS belum membuat indeks klasifikasi kelompok pendidik atau guru khususnya di lingkungan Kementerian Agama. Hal ini penting, karena guru merupakan garda terdepan dalam pelayanan pendidikan. Dengan mengetahui indeks kebahagiaan guru maka dapat dilakukan perbaikan dan pengembangan kebijakan pengelolaan tenaga pendidik.

Sekolah merupakan salah satu tempat sosialisasi nilai dan pengetahuan bagi siswa. Guru merupakan pendidik profesional dengan tugas utama mendidik, mengajar, membimbing, mengarahkan, melatih, menilai, dan mengevaluasi peserta didik pada pendidikan anak usia dini jalur pendidikan formal, pendidikan dasar, dan pendidikan menengah. Kebijakan pengelolaan pendidik seharusnya memperhatikan aspek sosial dan individual. Terlebih guru di Madrasah memiliki tanggung jawab tidak hanya memberikan pemahaman keilmuan namun juga harus memberikan pembelajaran moral dan iman. Layanan sekolah dapat dikatakan bermutu atau berkualitas jika dilaksanakan oleh tenaga pendidik yang melaksanakan kebijakan pendidikan dengan rasa bahagia. Namun demikian belum diketahui indeks kebahagiaan guru yang bertugas di MAN di Provinsi DKI Jakarta dan Provinsi Banten, sehingga diketahui pola atau kecenderungan kebahagiaan guru. Selain itu juga belum diketahui secara mendalam tentang bagaimana seharusnya kebahagiaan guru yang bertugas di MAN di Provinsi DKI Jakarta dan Provinsi Banten.

Penelitian dalam artikel ini mengkaji indeks kebahagiaan guru yang bertugas di MAN di Provinsi DKI Jakarta dan Provinsi Banten. Selanjutnya mengkaji secara mendalam tentang bagaimana guru yang bertugas di MAN di Provinsi DKI Jakarta dan Provinsi Banten, sehingga dapat memberikan kontribusi terhadap kebijakan pengelolaan kebahagiaan guru. 
Penelitian ini diharapkan dapat bermanfaat secara praktis bagi penentu kebijakan pengelolaan guru terutama di Provinsi DKI Jakarta dan Provinsi Banten. Secara praktis juga penelitian ini dapat memberikan informasi kepada penentu kebijakan untuk mengetahui potensi kebahagiaan khususnya kebahagiaan guru yang bertugas di MAN di Provinsi DKI Jakarta dan Provinsi Banten. Dengan pengelolaan kebahagiaan yang optimal maka layanan pendidikan di MAN Provinsi DKI Jakarta dan Provinsi dapat dilaksanakan dengan baik dan dapat mencapai tujuan pendidikan Madrasah yakni membentuk ilmu dan iman siswa. Secara akademis penelitian ini bermanfaat untuk menambah keilmuan kesejahteraan sosial.

Kajian teori dalam penelitian ini disajikan bagaimana kebahagiaan dikonstruksikan secara dinamis untuk masuk ke dalam pengetahuan. Pengungkapan kebahagiaan ini untuk menunjukkan bagaimana kebahagiaan masuk ke dalam ranah publik, yang kemudian memberikan justifikasi bagi negara untuk mengatur kebahagiaan, dalam bentuk penyusunan kebijakan yang berdasarkan pengukuran dan penelitian mendalam tentang kebahagiaan. Indeks kebahagiaan tidak hanya sebagai capaian angka statistik, namun juga dimaknai secara mendalam dan dikaji lebih lanjut untuk mendorong perbaikan dan pengembangan kebijakan berdasarkan hasil penelitian.

Kebahagiaan merupakan komponen utama dari good life. Sesuai dengan pendapat terebut Maniku, Sinolungan, Opod mengungkapkan kebahagiaan adalah suatu keadaan atau perasaan senang, tentram, damai, dan puas dalam diri seseorang (Maniku et al., 2014). Indeks kebahagiaan harus dimaknai dengan tepat, sehingga menjadi informasi yang berguna bagi pembuat kebijakan untuk menawarkan sebuah kebijakan. Penelitian Wibowo menunjukkan adanya reorientasi arah kebijakan pembangunan nasional dari ukuran makro kuantitatif (pertumbuhan) menuju ukuran yang lebih kualitatif (kebahagiaan) (Wibowo, 2016).

Kebahagiaan masyarakat dapat dijadikan parameter untuk menentukan pencapaian dari suatu Negara (Herdiani, Selviandro and Fitra, 2016). Faktor penentu kebahagiaan bukan hanya faktor material namun juga faktor non material. Secara teori, indikator keberhasilan pembangunan ekonomi suatu negara, selalu didasarkan pada perhitungan Produk Domestik Bruto (PDB) semata. Dan ukuran inilah yang selama ini selalu menjadi pedoman oleh pemerintah dalam menilai kinerja ekonominya, meskipun sebetulnya penggunaan konsep PDB sebagai indikator kesejahteraan ekonomi negara, dalam perjalanannya mengalami evolusi yang cukup signifikan. Evolusi pertama muncul seiring dengan fakta bahwa tingkat populasi penduduk antar negara sangat heterogen (Pascarina, 2015). Ada negara yang kaya namun populasi penduduknya juga relatif besar, sebaliknya ada negara yang kaya namun populasi penduduknya rendah. Adapula negara yang miskin dan populasi penduduknya besar dan sebaliknya. Keanekaragaman modalitas tersebut tentu akan menimbulkan kesalahan dalam intepretasi jika indikator kesejahteraan hanya menggunakan PDB semata.

Karenanya, kemudian muncul konsep PDB/PNB per kapita sebagai upaya mereduksi kelemahan tersebut. Tantangan berikutnya muncul ketika ada perbedaan standar biaya hidup antar negara. Tokyo di Jepang dan beberapa kota besar di Eropa dikenal sebagai kota dengan standar biaya hidup termahal di dunia. Sulitnya mengukur tingkat kebahagiaan, bukan berarti kebahagiaan seseorang tidak bisa diukur. Diperlukan formulasi khusus dalam mengukur tingkat kebahagiaan. 
Pendekatan yang digunakan dengan mengukur tingkat kepuasan hidup dalam berbagai ranah kehidupan yang penting dalam menjalani hidup. Seperti, kepuasan masyarakat terhadap kesehatan, pendidikan, pekerjaan, penghasilan dan pendapatan, keharmonisan keluarga, aset dan perumahan, kehidupan sosial, waktu luang, lingkungan, serta keamanan. Menilai kepuasan ini-pun tidak bisa diukur secara langsung. Seseorang harus melakukan evaluasi terhadap hidup yang sudah dijalaninya terlebih dahulu sebelum menilai kepuasannya. Sehingga sebelum ditanyakan kepuasan, seseorang harus dipandu dengan menanyakan berbagai pertanyaan berbagai hal objektif tentang apa yang sudah dialami, baru kemudian ditanyakan hal subjektif mengenai kepuasan terhadap capaian hidupnya. Penelitian tentang kebahagiaan dimaksudkan untuk mengungkap faktor-faktor kebahagiaan yakni sosial, kebijakan, dan fasilitas. Selain itu untuk mengungkap aktor kebahagiaan yakni pasangan, keluarga, teman, dan komunitas (Sujatmiko, 2016).

Hasil penelitian menunjukkan bahwa kebahagiaan di Indonesia secara positif dipengaruhi oleh pendapatan, tingkat pendidikan, status kesehatan yang dirasakan dan modal sosial. Namun demikian, modal sosial yang berkaitan dengan agama dan etnis tidak memiliki pengaruh yang signifikan terhadap kebahagiaan. Semua prediktor bersifat robust. Karakteristik demografi menginformasikan bahwa orang yang menikah, bukan kepala rumah tangga, tinggal di daerah perkotaan, berada di luar pulau Jawa-Bali dan dari suku Jawa lebih bahagia daripada yang lain. Riset ini juga menemukan bahwa tidak terdapat perbedaan dalam tingkat kebahagiaan antara pria dan wanita. Kemudian, hubungan antara kebahagiaan dan usia menunjukkan kurva yang berbentuk U. Terakhir, efek marjinal menunjukkan efek yang berbeda untuk setiap tingkat kebahagiaan karena perubahan unit variabel independen (Pascarina, 2015). Namun penelitian ini tidak membahas lebih khusus indeks kebahagiaan berdasarkan jenis pekerjaan terutama guru.

Dengan mengetahui indeks kebahagiaan pendidik, maka dapat dilakukan pemeliharaan. Pemeliharaan adalah usaha mempertahankan atau meningkatkan kondisi fisik, mental, sikap karyawan agar tetap loyal dan bekerja produktif untuk menunjang tercapainya tujuan perusahaan. Tujuan pemeliharaan adalah meningkatkan produktivitas kerja karyawan, meningkatakan disiplin dan menurunkan absensi karyawan, meningkatkan loyalitas dan menurunkan turn over karyawan, meningkatkan ketenangan, rasa aman, dan kesehatan karyawan, meningkatkan kesejahteraan karyawan dan keluarganya, memperbaiki kondisi fisik, mental, dan sikap karyawan, mengurangi konflik serta menciptakan suasana yang harmonis. Selain itu selayaknya indeks kebahagiaan dapat digunakan sebagai dasar penetapan kebijakan tentang pengelolaan pendidik. Hal ini dapat terlihat berdasarkan kualitas sumber daya manusia pendidikan dipengaruhi oleh faktor internal dan eksternal yang dimana dua faktor ini saling terkalit dalam hal peningkatan kapasitas diri manusia. Faktor internal terkait dengan motivasi atau niat belajar manusia, kemudian faktor eksternalnya yaitu terkait dengan sumber belajar, lingkungan, sosial, ataupun budaya. Jika dua hal ini dapat berjalan dengan selaras dan tetap mengikuti asas dan landasan pendidikan yang ada maka prosentase pencapaian tujuan pendidikan di Indonesia akan tergolong tinggi.

Penelitian Irianto dan Subandi mengenai studi fenomenologis kebahagiaan guru di pedalaman Papua menunjukkan bahwa, kebahagiaan guru karena siswa dapat mengikuti proses pembelajaran dan melanjutkan ke jenjang yang lebih tinggi, dapat menunjukkan identitas sebagai guru di pedalaman Papua juga merupakan kebahagiaan guru, adanya kerjasama dan saling membantu 
diantara para guru merupakan penyebab kebahagiaan guru, selain itu dukungan masyarakat setempat dan keluarga juga merupakan determinan kebahagiaan (Irianto and Subandi, 2015). Namun penelitian tersebut tidak menunjukkan tingkat kebahagiaan guru dan hanya guru laki-laki yang diteliti dalam penelitian ini, serta penelitian ini dilaksanakan di daerah pedalaman Papua, yang belum terdampak arus modernisasi dan teknologi.

Prasetyo mengungkapkan dalam studinya mengenai kebahagiaan dosen, bahwa faktor yang mempengaruhi kebahagiaan adalah relasi dengan orang lain (relasi dengan mahasiswa, relasi dengan sesama dosen, relasi dengan pejabat struktural pendidikan tinggi), keterlibatan penuh dalam tugas, penemuan makna spiritualitas dan pengembangan karir (Prasetyo, 2015). Penelitian ini merupakan penelitian deskriptif, menggunakan alat ukur Developmental goal, yang disebut career happiness plan. Namun penelitian ini belum melaksanakan wawancana mendalam dan penilaian atasan untuk meningkatkan validitas dan analisis mendalam serta menyeluruh, sehingga dapat memahami makna kebahagiaan yang luas dan kompleks.

Meiza melakukan kajian tentang perbedaan kebahagiaan guru Pegawai Negeri Sipil (PNS) dan Non-PNS, hasil kajian ini menunjukkan tidak ada perbedaan kebahagiaan diantara dua kelompok sampel tersebut. Mean empirik kedua kelompok sampel tersebut berada pada kategori yang tinggi, baik berdasarkan jenis kelamin dan usia (Meiza, 2016). Namun penelitin ini belum juga mengkaji sisi positif dari kebahagiaan guru secara mendalam.

Wulandari dan Widyastuti juga mengkaji tentang kebahagaiaan, yang menunjukkan bahwa ada lima faktor yang membuat seseorang bahagia di tempat kerja yaitu (1) hubungan positif dengan orang lain seperti dukungan dari rekan kerja dan atasan, (2) prestasi seperti keberhasilan menyelesaikan tugas, kesesuaian pekerjaan, dan mengembangkan diri, (3) lingkungan kerja fisik seperti fasilitas, (4) kompensasi seperti gaji dan insentif, (5) kesehatan seperti badan sehat dan rileks (Meiza, 2016). Secara garis besar, dari beberapa faktor tersebut faktor hubungan positif dengan orang lain memiliki persentase terbesar. Hal ini menunjukkan bahwa hubungan positif sesama rekan kerja merupakan salah satu sumber kebahagiaan di tempat kerja.

\section{Metode}

Metode yang digunakan dalam pemberdayaan ini adalah metode intervensi langsung. Program pemberdayaan ini merupakan program pemberdayaan masyarakat berbasis lingkungan sekolah. Tujuan dari pemberdayaan ini adalah mewujudkan penyelenggara pendidikan yang kompeten dalam melaksanakan pembelajaran. Program yang dilaksanakan adalah seminar dalam memetakan pengetahuan bersama akan kebahagiaan. Dengan memahami dan memetakan kondisi bahagia di lingkungan persekolahan, maka suasanan atau kebijakan di sekolah dapat disusun berdasarkan kondisi kebahagiaan tersebut.

\section{Hasil dan Pembahasan}

Pada pendampingan ini kepala sekolah dan masing-masing guru diminta untuk mengungkapkan segala hal yang dirasakan ketika melaksanakan tugas mengajar. Hal tersebut meliputi hal yang menghambat dan mendukung tugasnya. Selain itu kepala sekolah dan guru 
diminta untuk mengungkapkan apa yang dirasakan, untuk mengetahui tingkat perasaan yang dimilikinya. Pemahaman tersebut terbukti dengan kepala sekolah dan guru mampu menjawab dan menganalisis dimensi-dimensi kebahagiaan yang mereka miliki.

Pada dimensi kepuasan hidup ini, para guru merasa puas dengan jenjang pendidikan dan jenis pekerjaan yang dimiliki. Dengan jenjang pendidkan yang kebanyakan berasal dari kependidikan, maka menjadi guru adalah jenis pekerjaan yang sesuai. Selain itu para guru tersebut puas dengan tingkat pendapatan yang diperoleh. Namun demikian pada indikator dimensi kepuasan hidup yang memiliki skor rendah, terdapat pada kepuasan terhadap letak tempat tinggal yang jauh dari sekolah. Selain itu guru memiliki ketidakpuasan terhadap waktu luang untuk mengembangkan diri seperti membaca dan menulis ilmiah. Untuk tipe kepemimpinan juga menimbulkan ketidakpuasan guru yang bertugas di MAN. Waktu luang untuk mengembangkan kualitas materi ajar juga dinilai kurang oleh para guru.

Para guru memiliki tekat yang kuat untuk melaksanakan tugas mengajar dengan sebaikbaiknya. Para guru selalu berusaha untuk mengasah dan meningkatkan keterampilan dalam mengajar. Guru menghayati tugas profesional sebagai guru dan memiliki tekad yang kuat untuk memperbaiki kualitas profesional. Para guru berusaha untuk memberikan makna dalam setiap kegiatan profesional. Guru-guru menyadari bahwa mengajar harus dilaksanakan dengan sebaikbaiknya.

Pada dimensi kepuasan hidup, guru puas dengan jenjang pendidikan yang mereka miliki. Jenjang pendidikan yang mereka miliki, mereka memiliki keterampilan dan pengetahuan dalam melaksanakan tugas pengajaran. Dengan bekal jenjang pendidikan yang mereka miliki, para guru dapat mengurangi emosi negatif berupa rasa tertekan dalam memberikan layanan pengajaran kepada para siswa.

Tingkat kemampuan mengajar juga pada tingkat kepuasan yang tinggi karena rata-rata para guru lolos sertifikasi profesi guru. Selain itu juga sebagian besar guru lulus Uji Kompetensi Guru (UKG). Namun demikian mereka mengalami kesulitan dalam pelaksanaan UKG tersebut. Banyak guru yang keberatan mulai dari teknisnya yang sulit karena harus online sementara tidak menguasai IT, dan banyak yang berfikiran bahwa UKG akan memutuskan tunjangan profesi bagi mereka yang dinyatakan belum berhasil menyelesaikan soal ujian dengan baik. Kemudian pemerintah menjelaskan bahwa UKG tidak digunakan sebagai standar guru untuk mendapatkan tunjangan profesi atau tidak, tapi hanya digunakan sebagai alat untuk memetakan kemampuan guru sehingga pemerintah mudah dalam memberikan pembinaan terhadap profesi guru. Yaitu bahwa tujuan UKG adalah (1) Pemetaan penguasaan kompetensi guru (kompetensi pedagogik dan profesional) sebagai dasar pertimbangan pelaksanaan program pembinaan dan pengembangan profesi guru dalam bentuk kegiatan pengembangan keprofesian berkelanjutan; (2) Sebagai entry point penilaian kinerja guru dan sebagai alat kontrol pelaksanaan penilaian kinerja guru (Zaenal Khayat, 2013). Hal itu juga yang membuat suasana emosi guru menjadi tidak pasti. Yang secara tidak langsung mempengaruhi emosi negatif para guru. Selain itu kebijakan yang berubah juga menjadi faktor yang mempengaruhi kondisi emosi guru. Kebijakan tersebut seperti kurikulum yang berubah, suasana kerja yang berubah. Penerapan sekolah lima hari yang menimbulkan polemik. Bahkan penerapan Kurikulum 
2013 yang "terpaksa" dibatalkan akibat guru yang belum paham betul. Banyak guru yang bingung sehingga pembelajaran tidak berjalan optimal. Maka upaya meningkatkan kompetensi guru sebagai pelaksana kurikulum di kelas sangatlah penting. Karena sebaik apapun kurikulum yang ada, tidak akan bisa berjalan dengan baik tanpa didukung guru yang berkualitas (Syarifudin Yunus, 2016). hasil Uji Kompetensi Guru (UKG) tahun 2015, rata-rata nasional hanya 44,5 jauh di bawah nilai standar 75. Bahkan kompetensi pedagodik, yang menjadi kompetensi utama guru pun belum menggembirakan. Masih banyak guru yang cara mengajarnya kurang baik, cara mengajar di kelas membosankan (Syarifudin Yunus, 2016).

Untuk pengembangan karir, para guru merasa puas dengan karir yang dimilikinya saat ini. Menurut Lloyd L. Byars dan Leslie W. Rue (2008:194), "career development is an angoing, formalized effort by an organization that focuses on developing and enriching the organization's human resources in light of both the employees' and the organization's needs". Pengembangan karier adalah upaya yang terus menerus, usaha formal organisasi yang fokus pada pengembangan, dan penyediaan sumber daya manusia di organisasi baik bagi kebutuhan pegawai maupun kebutuhan organisasi. Menurut Robert N Luissier (2008:129), "career development is the process of gaining skill, experience, and education to achieve career objectives". Pengembangan karier adalah proses mendapatkan keterampilan, pengalaman, dan pendidikan untuk mencapai tujuan karier. Menurut Danang Sunyoto (2012:184), pengembangan karier pegawai dapat dilakukan melalui dua cara yaitu: 1) cara diklat, contoh: a) melanjutkan studi atau pendidikan pegawai baik di dalam negeri maupun diluar negeri, b) memberikan pelatihan baik di dalam organisasi maupun di luar organisasi, c) memberikan pelatihan sambil bekerja (on the jon traning), 2) cara non diklat, contoh: a) memberikan penghargaan kepada pegawai, b) memberi sanksi pegawai, c) mempromosikan pegawai ke jabatan yang lebih tinggi, d) merotasi pegawai ke jabatan lain yang setara dengan jabatan semula (As'ad, n.d.).

Tugas utama guru sebagai pendidik professional adalah mendidik, mengajar, membimbing, mengarahkan, melatih, menilai dan mengevaluasi peserta didik pada jalur pendidikan normal. Tugas utama itu akan efektif jika guru memiliki derajat profesionalitas tertentu yang tercermin dari kompetensi, kemahiran, kecakapan, atau keterampilan yang memenuhi standar mutu dan norma etik tertentu. Secara formal, guru professional harus memenuhi kualifikasi akademik minimum S-1/DIV dan bersertifikat pendidik sesuai dengan peraturan perundang-undangan. Guru-guru yang memenuhi criteria professional inilah yang akan mampu menjalankan fungsi utama nya secara efektif dan efisien untuk mewujudkan proses pendidikan dan pembelajaran sejalan dengan tujuan pendidikan nasional, yakni mengembangkan potensi peserta didik agar menjadi manusia yang beriman dan bertakwa, berakhlak mulia, sehat, berilmu, cakap, kreatif, mandiri serta menjadi warga Negara yang demokratis dan bertanggung jawab.

Di dalam UU Nomor 74 tahun 2008 tentang guru dibedakan dan pengembangan kompetensi guru yang belum dan yang sudah berkuakifikasi S-1 atau D-IV. Pengembangan dan peningkatan kualifikasi akademik bagi guru yang belum memenuhi kualifikasi S-1 dilakukan melalui pendidikan tinggi program S-1 pada perguruan tinggi yang menyelenggarakan program pendidikan tenaga kependidikan dan/atau program pendidikan non kependidikan. 
Pengembangan dan peningkatan kompetensi bagi guru yang sudah memiliki sertifikat pendidik dilakukan dalam rangka menjaga agar kompetensi keprofesiannya tetap sesuai dengan perkembangan ilmu pengetahuan, teknologi, seni, budaya dan/atau olahraga (PP nomor 74 tahun 2008). Pengembangan dan peningkatan kompetensi dimaksud dilakukan melalui system pembinaan dan pengembangan keprofesian guru berkelanjutan yang dikaitkan dengan perolehan angka kredit jabatan fungsional.

Kegiatan pengembangan dan peningkatan professional guru yang sudah memiliki sertifikat pendidik dimaksud dapat berupa: kegiatan kolektif guru yang meningkatkan kompetensi dan/atau keprofesian, pendidikan dan pelatihan, pemagangan, publikasi ilmiah atas hasil penelitian atau gagasan inovatif, karya inovatif, presentasi pada forum ilmiah, publikasi buku teks pelajaran yang lolos penilaian BSNP, publikasi buku penggayaan, publikasi buku pedoman guru, publikasi pengalaman lapangan pada pendidikan khusus dan/atau pendidikan layanan khusus, dan/atau penghargaan atau prestasi atau dedikasi sebagai guru yang diberikan oleh pemerintah atau pemerintah daerah.

Aspek utama yang bersentuhan langsung dengan nasib para guru adalah Teacher Management (Manajemen Guru). Menurut Worldbank (1998: 20) disebutkan bahwa guru juga mempunyai kesempatan promosi (peningkatan). Struktur karier bagi guru pada pendidikan dasar berbentuk piramida. Promosi guru selalu berarti bahwa kerja guru beralih ke bidang administrasi dan meninggalkan tugasnya sebagai pengajar di kelas. Pola semacam itu mempunyai efek negatif terhadap moral guru dan menurunkan kualitas hasil pengajaran karena guru yang senior memperoleh promosi bukan sebagai guru, melainkan sebagai tenaga administrasi. Beberapa negara seperti Australia dan Irlandia mengembangkan sejumlah jabatan guru, sebagai contoh jabatan bertingkat yang lebih difokuskan dalam hal tanggung jawab khusus. Jabatan-jabatan itu menambah promosi jabatan tradisional yang sudah ada, yaitu kepala dan deputi kepala. Tugas-tugas yang berkaitan dengan jabatan khusus tersebut dipusatkan.

Kenaikan pangkat dan jabatan fungsional guru dalam rangka pengembangan karir merupakan gabungan dari angka kredit unsur utama dan penunjang ditetapkan sesuai dengan permenneg PAN dan BR Nomor 16 Tahun 2009. Tugas -tugas guru yang dapat dinilai dengan angka kredit untuk keperluan kenaikan pangkat dan/atau jabatan fungsional guru mencakup unsur utama dan unsure penunjang. Unsure utama kegiatan yang dapat dinilai sebagai angka kredit dalam kenaikan pangkat guru terdiri atas: (a) pendidikan; (b) pembelajaran/pembimbingan dan tugas tambahan dan/atau tugas lain yang relevan dengan fungsi sekolah/madrasah, dan (c) pengembangan keprofesian berkelanjutan $(\mathrm{PKB})$.

Dari sub dimensi pendapatan, guru cukup puas dengan pendapatan yang mereka miliki. Hal ini dikarenakan guru memilih untuk berkair di bidang pendidikan, yang notabene bidang non profit, yang tentunya dari segi gaji berbeda dengan bidang profit. Selain itu mereka tidak memiliki keterampilan lain untuk berkarir di bidang profit.

Guru madrasah perlu mendapatkan perhatian yang lebih. Ia mengatakan salah satu tujuan dari PGM Indonesia atau sebagai organisasi profesi guru adalah mewadahi dan meningkatkan profesionalisme kompetensi dan kesejahteraan guru madrasah.

Kondisi alat transportasi yang digunakan dalam bertugas seharusnya juga dalam kondisi yang baik. Jarak sekolah dengan kediaman para guru, mempengaruhi kondisi emosi para guru. Kondisi lalu lintas yang padat, cukup menguras emosi para guru. Para guru harus berangkat subuh, atau 
menggunakan alat transportasi ojek online, untuk sampai sekolah tepat waktu. Begitupun ketika pulang dari bertugas, harus juga berada dalam lalu lintas yang padat.

Kondisi lingkungan eksternal dan internal sekolah, menjadi perhatian para guru, sehingga dapat melaksanakan evaluasi terhadap lingkungannya. Lingkungan eksternal dan lingkungan internal mempunyai peran yang cukup penting dalam usaha pengambilan keputusan guna mewujudkan visi misi lembaga pendidikan Islam yang diinginkan. Interaksi antar lingkungan internal maupun eksterrnal akan sangat mempengaruhi kemampuan serta strategi-strategi penting bagi para pengambil keputusan. Lingkungan (environment) dalam lingkup yang luas memiliki arti sesuatu yang bersifat fisik dan non fisik yang mempengaruhi kehidupan seseorang. Lingkungan ternyata sangat berpengaruh terhadap pengembangan kemampuan sebuah lembaga pendidikan Islam.

Kondisi waktu luang untuk melaksanakan kegiatan ilmiah, dinilai kurang oleh para guru. Karena para guru berfokus pada kegiatan pengajaran. Para guru diwajibkan melaksanakan tugas pengajaran dalam batasan minimal jam. Waktu luang bagi seorang guru merupakan sesuatu yang berharga. Guru membutuhkan waktu luang untuk membaca dan mempersiapkan materi ajar yang dipandunya. Dengan membaca, para guru dapat mempersiapkan dan mengembangkan materi ajar dengan baik. Para guru harus siap dengan perkembangan berkaitan dengan teknologi dan informasi, serta kondisi peserta didik. Selain membaca, guru dituntut untuk menulis, minimal menulis rencana pelaksanaan pembelajaran (RPP), dan mengisi form evaluasi siswa. Selain itu diharapkan guru memanfaatkan komunitas akademis. Komunitas akademis tersebut bisa dimanfaatkan untuk berdiskusi akademis.

Tipe kemimpinan kepala sekolah cukup membuat guru memiliki emosi positif. Keberhasilan pendidikan di sekolah sangat ditentukan oleh keberhasilan kepala sekolah dalam mengelola tenaga kependidikan yang tersedia di sekolah. Kepala sekolah merupakan salah satu komponen pendidikan yang berpengaruh dalam meningkatkan kinerja guru. Kepala sekolah bertanggung jawab atas penyelenggaraan kegiatan pendidikan, administrasi sekolah, pembinaan tenaga kependidikan lainnya, dan pendayagunaan serta pemeliharaan sarana dan prasarana. Kepala sekolah sebagai pimpinan tertinggi yang sangat berpengaruh dan menentukan kemajuan sekolah harus memiliki kemampuan administrasi, memiliki komitmen tinggi, dan luwes dalam melaksanakan tugasnya. Kepemimpinan kepala sekolah yang baik harus dapat mengupayakan peningkatan kinerja guru melalui program pembinaan kemampuan tenaga kependidikan. Oleh karena itu kepala sekolah harus mempunyai kepribadian atau sifat-sifat dan kemampuan serta keterampilan-keterampilan untuk memimpin sebuah lembaga pendidikan. Dalam perannya sebagai seorang pemimpin, kepala sekolah harus dapat memperhatikan kebutuhan dan perasaan orang-orang yang bekerja sehingga kinerja guru selalu terjaga (Endy, 2009).

Tingkat kepuasan terhadap efektivitas MGMP adalah cukup tinggi. Melalui MGMP diharapkan guru dapat mempertahankan kualitas profesionalismenya sesuai tuntutan jaman dan kebutuhan sekolah. Penjelasan tersebut memperlihatkan bahwa penyelenggaraan MGMP memiliki peranan penting dalam peningkatan kompetensi pedagogik guru, namun memang dalam penyelenggaran kegiatan MGMP pun guru masih dihadapi dengan berbagai permasalahan yang menyebabkan penyelanggaraan kegiatan tersebut belum optimal.

Guru bersinergi dengan guru dalam melaksanakan tugas mengajar. Guru dan orang tua adalah dua pihak yang sama-sama menginginkan proses belajar mengajar di sekolah berjalan lancar. Oleh karena itu guru dan orang tua perlu membangun komunikasi yang positif. 
Terkadang, guru merasa terganggu karena merasa orang tua terlibat terlalu dalam, sedangkan orang tua merasa jika mereka diberikan penjelasan secara berkala tentang kondisi dan proses belajar mengajar akan membuat orang tua merasa menjadi bagian dari "team" dan akan support serta memberikan masukan untuk peningkatan kualitas belajar mengajar. Oleh karena itu diperlukan komunikasi yang efektif antara guru dan orang tua (Dewi Kurnia Indrastuti, 2017).

Pada dasarnya, kewajiban orang tua murid dan guru di sekolah adalah sama, yaitu memastikan anak/murid mendapatkan pendidikan yang baik. Dibutuhkan kerja-sama yang dijalin dengan baik pula untuk kepentingan anak/murid. Baik guru maupun orang-tua murid harus saling menghormati dan menghargai. Jika komunikasi antara orang-tua murid dan guru tidak dibangun dengan baik, akan timbul konflik yang dapat merugikan anak/murid. Sekolah harus memiliki program khusus untuk mempertemukan guru-guru dan orang-tua murid secara rutin. Pada proses ini dapat dilakukan kegiatan-kegiatan yang dapat mendekatkan guru dan orang-tua murid. Fungsinya adalah untuk menghilangkan rasa keraguan, rasa curiga, rasa sungkan dan sebagainya agar mereka dapat bekerja-sama memberikan pendidikan bagi anak/murid (Ronald Husasuhut, 2017).

Pengelolaan perasaan penting untuk para guru. Kecerdasan emosional merupakan salah satu kompetensi personal yang wajib dimiliki oleh para guru. Dalam penelitian ini skala perasaan yang dimiliki oleh para guru Madrasah Aliyah cukup tinggi. Para guru cukup mampu untuk mengelola perasaan yang dimiliki, termasuk mengendalikan kecemasan, rasa tidak nyaman, marah, memiliki tekad yang kuat untuk mendidik para siswa, memiliki tekad yang kuat untuk mencapai tujuan pendidikan nasional, memiliki rasa bangga dalam menjalankan kewajiban menjadi guru, bangga terhadap prestasi yang dicapai oleh siswa, bangga ketika siswa memiliki sikap yang baik.

Perasaan adalah suatu pernyataan jiwa, yang sedikit banyak bersifat subjektif, untuk merasakan senang atau tidak senang dan yang tidak bergantung kepada perangsang dan alat-alat indra. Sedangkan menurut Hukstra, perasaan adalah suatu fungsi jiwa yang dapat mempertimbangkan dan mengukur sesuatu menurut rasa senang dan tidak senang. Perasaan merupakan suatu keadaan dalam kesadaran manusia yang karena pengaruh pengetahuannya dinilai sebagai keadaan positif dan negatif (Miswari, 2017).

Pada dimensi makna hidup, guru memiliki tingkat makna hidup yang tinggi. Para guru memahami betul tentang apa yang mereka laksanakan dalam kegiatan pengajaran. Para guru memiliki harapan dan cita-cita dalam menjalankan kegiatan mengajar, mereka menitipkan masa depan bangsa pada siswa yang mereka ajar, dengan menitipkan pengetahuan kepada siswa, para guru berharap ilmu yang terus mengalir dalam diri siswa, sehingga dapat berperan dalam masyarakat. Para guru tidak mudah mengubah tekad yang sudah mereka buat, yakni akan terus mendidik para anak bangsa. Para guru memiliki tekat yang kuat untuk selalu meningkatkan kualitas diri, untuk meningkatkan kualitas pengajaran. Profesi guru merupakan hal terpenting dalam kehidupan mereka. Kehiduan di lingkup persekolahan memberikan semangat untuk mengisi kehidupan, karena para guru memiliki pandangan bahwa dengan ilmu yang bermanfaat yang mereka titipkan pada para siswa, maka amal baik akan senantiasa mengalir pada guru.

\section{Kesimpulan dan Rekomendasi}

Setelah pendampingan, baik kepala sekolah berserta guru memahami tentang pengelolaan sumber daya manusia. Pemahaman tersebut meliputi pengelolaan sumber daya manusia di lingkungan sekolah, harus dilaksanakan seara komprehensif, baik secara individual dan kelompok. Pemahaman secara individual tersebut mencakup pemahaman mengenai sumbe daya manusia di sekolah, dalam melaksanakan tugasnya harus bahagia. Bahwa kebahagiaan berasal dari pemahaman 
akan tugas dan perannya, hal-hal yang menyebabkan bahagia dalam melaksanakan tugasnya. Dengan adanya pemahaman tersebut diharapkan stress kerja dapat dikendalikan, sehingga tugastugas mengajar dapat diselesaikan dengan baik.

\section{Daftar Pustaka}

10 Tawuran Pelajar Yang Merenggut Jiwa di Tahun 2016 - Serba Top 10 (2016). Available at: http://10daftarsaya.blogspot.com/2017/03/tawuran-pelajar-perenggut-jiwa-2016.html (Accessed: 13 October 2018).

Aditya Akbar Hakim (2017) Ragam Kebahagiaan Seorang Guru. Available at: https://mepnews.id/2017/07/08/ragam-kebahagiaan-seorang-guru/ (Accessed: 13 October 2018).

Arvan Pradiansyah (2013) Mungkinkah Mengukur Kebahagiaan? | SWA.co.id. Available at: https://swa.co.id/swa/my-article/column/mungkinkah-mengukur-kebahagiaan (Accessed: 7 October 2018).

Badan Pusat Statistik (2017) PEDOMAN PENCACAH SUSENAS MARET 2017. Badan Pusa. Jakarta.

Brannen, J. (2017) 'Mixing Methods: Qualitative and Quantitative Research.' Available at: http://www.tandfebooks.com/isbn/9781315248813.

Bryman, A. and Bell, E. (2015) Business Research Methods. New York.

CNN (2018) Studi: Rangking Kebahagiaan Indonesia di Dunia 'Jeblok'. Available at: https://www.cnnindonesia.com/gaya-hidup/20180329074022-277-286709/studi-rangkingkebahagiaan-indonesia-di-dunia-jeblok (Accessed: 13 October 2018).

Creswell, J. W. and Creswell, J. D. (2018) Research Design: Qualitative, Quantitative, And Mixed Methods Approaches.

Dewasasri M. Wardani (2016) Satu Harapan: Perencanaan Pembangunan di Indonesia Dari Masa ke Masa. Available at: http://www.satuharapan.com/read-detail/read/perencanaanpembangunan-di-indonesia-dari-masa-ke-masa (Accessed: 13 October 2018).

Eki Akhwan (2013) Kebahagiaan Seorang Guru. Available at: https://equshay.wordpress.com/2013/11/21/kebahagiaan-seorang-guru/ (Accessed: 13 October 2018).

Haryudi (2018) Duel Maut ala Gladiator Siswa SMP Bogor untuk Di-upload... Available at: https://metro.sindonews.com/read/1327466/170/duel-maut-ala-gladiator-siswa-smp-bogoruntuk-di-upload-ke-youtube-1533289769 (Accessed: 13 October 2018).

Herdiani, A., Selviandro, N. and Fitra, D. I. (2016) 'Pengukuran Indeks Kebahagiaan Masyarakat Kota Bandung dari Jejaring Sosial Twitter Menggunakan Ontologi dengan Paradigma Bottom-up', in e-Proceeding of Engineering, pp. 3596-3602.

Ica Haiti (2018) Pentingnya Motivasi Kebahagiaan Dalam Hidup Agar Sukses I Blog Berita Fashion, Kesehatan, Makanan, dan lainnya | Itecahaiti.org. Available at: http://itecahaiti.org/pentingnya-motivasi-kebahagiaan-dalam-hidup-agar-sukses/ (Accessed: 13 October 2018).

Irianto and Subandi (2015) 'Studi Fenomenologis Kebahagiaan Guru di Papua', Gadjah Mada Journal of Psychology, 1(3), pp. 140-166.

Kabar Banten (2017) Indeks Kebahagiaan di Indonesia, Provinsi Banten Nyaris Paling Buncit. Available at: https://www.kabar-banten.com/indeks-kebahagiaan-di-indonesia-provinsibanten-nyaris-paling-buncit/ (Accessed: 13 October 2018).

Khadijah (2017) Kebahagiaan Hakiki Menurut Ajaran Islam. Available at: http://khajizah09.blogspot.com/2017/06/kebahagiaan-hakiki-menurut-ajaran-islam.html 
(Accessed: 13 October 2018).

Koo, H. et al. (2016) 'Dimensions of Social Well-being and Determinants in Korea: Personal, Relational, and Societal Aspects', The Senshu Social Well-being Review, 3(3), pp. 37-58.

Koran Jakarta (2017) BPS: Warga DKI Bahagia Kalau Keluarga Harmonis | Koran Jakarta. Available at: http://www.koran-jakarta.com/bps--warga-dki-bahagia-kalau-keluargaharmonis/ (Accessed: 13 October 2018).

Lavrakas, P. J. (2008) 'Encyclopedia of Survey Research Methods'. Thousand Oaks, Calif.: SAGE Publications. Available at: http://www.credoreference.com/book/sagesurveyr.

Maniku, S. F. S. et al. (2014) 'Hubungan Kebahagiaan Dengan Status Sosial Pada', Jurnal eBiomedik (eBM), 2(November), pp. 3-6.

Meiza, C. (2016) 'Perbedaan Kebahagiaan Pada Guru Differences Happiness on Civil Servants', Jurnal Ilmiah Psikologi, 9(2), pp. 132-141.

MERTENS, D. M. (2018) RESEARCH AND EVALUATION IN EDUCATION AND PSYCHOLOGY: integrating diversity with quantitative, qualitative, and mixed methods. [S.1.]: SAGE PUBLICATIONS.

Pascarina, C. (2015) 'Mengatur Kebahagiaan: Memaknai Indeks Kebahagiaan Sebagai Instrumen Kebijakan Pembangunan', in Seminar Nasional Ilmu Sosial dan Ilmu Politik (SNISIP) FISIP UNS dengan tema Gender Politik dan Pembangunan di Indonesia: Perspektif Multidisiplin, pp. 203-213.

Plano Clark, V. L. and Creswell, J. W. (2009) The Mixed Methods Reader. Los Angeles: SAGE.

Prasetyo, A. R. (2015) 'Gambaran Career Happiness Plan Pada Dosen', Jurnal Psikologi Undip, 14(2), pp. 174-182. doi: 10.14710/jpu.14.2.174-182.

Reza Wahyu (2012) 3 Tips Bekerja Bersemangat oleh Reza Wahyu - Kompasiana.com. Available at: $\quad$ https://www.kompasiana.com/rezawahyu/5517f798813311ad689de5c8/3-tips-bekerjabersemangat (Accessed: 7 October 2018).

Sapaat, A. (2016) Rahasia Kebahagiaan Guru | Republika Online. Available at: https://www.republika.co.id/berita/dunia-islam/hikmah/16/03/23/o4hbx8301-rahasiakebahagiaan-guru (Accessed: 13 October 2018).

Sujatmiko, I. G. and friends (2016) 'Social Well-being Research and Policy in Indonesia', The Senshu Social Well-being Review, 3(3), pp. 86-90.

Wibowo, M. G. (2016) 'Kebijakan Pembangunan Nasional: dari Pertumbuhan (Growth) Menuju Kebahagiaan (Happiness)', Asy-Syir'ah Jurnal Ilmu Syari'ah dan Hukum, 50(1).

Woodside, A. G. (2010) 'Case Study Research: Theory, Methods, Practice'. Bingley: Emerald Group Pub. Available at: http://public.eblib.com/choice/publicfullrecord.aspx?p=554822. 